\title{
MEDICAL MALPRACTICE AS A TORT IN THE U.S., AS A CRIME IN ITALY: FACTORS, CAUSES, PATHS AND OUTCOMES
}

\begin{abstract}
ANDREA DI LANDRO ${ }^{1}$
Abstract: The aim of the paper is, firstly, to try to understand the reasons for the different approaches to medical malpractice in two legal systems taken as models: the U.S., where professional negligence is almost exclusively subject of tort law; Italy, where criminal law instruments are instead widely used. The different extent of criminal responsibility for negligence and omission seems connectable to different political and cultural models: individualistic liberalism, on the one hand, solidarist statism and communitarianism, on the other hand; in juridical terms, to the ideal contrast between the reactive State and the active State; to the different approach to the relationship between subject and body, dominical-individual versus collectivistsocial; with a tendential "privatization" of the health-good, in the US model, and a "socialization" of the good-health itself, in the Italian model. Secondly, the paper tries, in a comparative perspective, to evaluate these different approaches, in terms of access to justice, paths and outcomes of the two models. The article attempts to highlight the strengths and the weaknesses of the contingent-fee system in the U.S. tort arena, and of the criminal justice system as "free legal aid" in Italy: a balanced solution should also allow victims hindered by the costs and the length of civil actions the possibility of using these latter form of protection, avoiding that criminal justice is exploited for compensatory purposes. Indeed, tort law more easily can meet compensatory claims, due to the lower probative standard required, the preponderance of evidence, rather than the beyond any reasonable doubt standard, required in criminal law. Also in terms of outcomes, the main problems arising in the two systems need to be tackled: the problem of few persons compensated, allowing a greater number of injured parties to access to justice and obtain fair compensation; the problem of symbolic criminal convictions (observed in the Italian experience), avoiding the automatic use of suspended penalties and monetary penalties as substitute of penalties weighing on professional practice and freedom, since these automatic mechanisms limit the preventive effectiveness of the criminal sanction and run the risk of creating discrimination on a census basis.
\end{abstract}

Keywords: medical malpractice, negligence, omission, access to justice, standard of proof.

SUMMARY: I. Introduction. Medical malpractice in U.S. law. No criminal responsibility for personal injury negligence or involuntary manslaughter due to minor (not gross) negligence. From practical problems to political-criminal problems... II. (continued)...the distribution of omissive and negligent crimes, between individualistic liberalism, solidaristic statism and communitarianism; between the reactive State and the active State; between the individual model of property and the collective/communitarian model of inalienability; between "privatized" and "socialised" healthcare. III. "Access to justice", paths and outcomes: contingent fee in tort area and criminal justice as "free legal aid"; "preponderance of evidence" and "beyond reasonable doubt"; compensation for a few people and symbolic criminal convictions.

\footnotetext{
1 Associate Professor of Criminal Law, University of Central Sicily "Kore", Italy (andreadilandro@gmail.com).
} 


\section{Introduction. Medical malpractice in U.S. law. No criminal responsibility for personal injury negligence or involuntary manslaughter due to minor (not gross) negligence. From practical problems to political-criminal problems...}

In Anglo-American law, medical conducts with inauspicious outcomes are subject matter mainly in the arena of civil law (malpractice tort law).

In the arena of negligent liability, an important comparative difference is that in North-American criminal law, battery is generally punished only if commited with intent (so-called specific intent), and only exceptionally, in some jurisdictions, if due to negligence ${ }^{2}$.

On the contrary, in Italian criminal law we find the crime of personal injury negligence (punishable with imprisonment of up to three months, or with a fine up to 309 euro: articles 590 - 590 sexies of the Italian criminal code), in addition to the crime of negligent homicide (punishable ex officio, as is standard in the Italian procedural system, with imprisonment from six months to five years: art. 589 - 590 sexies of the Italian criminal code).

In common law, negligence has historically been approached autonomously with respect to different areas of the legal system. In criminal proceedings only gross negligence is relevant; in civil proceedings minor negligence is evaluated, in other words, unintentional fault. In fact, normally, negligence (also called carelessness) by health professionals and the related causal problems, especially about the omissive actus reus, are subject matter of civil law ${ }^{3}$.

Therefore, in the U.S., criminal responsibility of the doctor is traditionally more limited than civil responsibility.

In the context of criminal law, the first function of mental states (mens rea), with particular reference to negligence, is indeed to distinguish criminal and non-criminal conduct $^{4}$.

In U.S. law, unlike English law, great efforts have been undertaken to define gross negligence (criminal negligence), especially in the Model Penal Code (M.P.C.), Sec. $\S$ 2.02, lett. d): «A person acts negligently with respect to the material element of a crime when he/she should be aware of the substantial and unjustified risk related to his / her behavior. The risk must be of such a nature and entity that its failure to perceive by the agent subject, given the nature and purpose of his conduct, as well as the circumstances

\footnotetext{
${ }^{2}$ V. Saunders v. State, 208 Tennessee 347, 345 S.W. 2d 899 (Tenn.1961), in LOEWY, Criminal Law, Eagan, Minnesota, 2003, 67.

${ }^{3}$ On the relationship between criminal and civil negligence, in UK law, see HERRING \& PALSER, The Duty of Care in Gross Negligence Manslaughter, in Crim. L. Rev., 2007, p. 24.

${ }^{4}$ BLOCH-McMUNIGAL, Criminal Law: A Contemporary Approach. Cases, Statutes, and Problems, New York, 2005, p. 210.
} 
known to him, involves a serious deviation from the standards of diligence that a reasonable person would observe in the same circumstances».

It must be said that this autonomous, complex definition of criminal negligence, principally based on two elements "Substantial and unjustified risk of which the subject should be aware" and the "lack of perception that implies a serious deviation from the standards of diligence" ("failure to perceive" that "involves a serious deviation from the standard of care"), does not receive unanimous approval by the commentators ${ }^{5}$. In criminal proceedings, the fact that mental state is essentially a question of degree usually causes problems, from both a theoretical and a practical point of view ${ }^{6}$.

In various U.S. jurisdictions, in order to put into effect and apply the Model Penal Code in case law, several epithets are used to describe the amount of negligence necessary to integrate negligent homicide. The most typical are: «criminal negligence», "gross negligence» and «culpable negligence». "About the only certainty of meaning one can ascribe to these epiteths - to quote a current U.S. manual ${ }^{7}$ - is that they require more than ordinary negligence, $i$. e., more than would be required in a civil case. Undesirable as this lack of certainty may be, it is probably unavoidable. Nobody has yet devised a formula which more precisely describes the degree of negligence necessary for involuntary manslaughter".

To explain the "something extra" necessary for criminal negligence and to avoid a reprehensible vicious circle of evaluation tests, focus is usually placed on the "moral defect» that "can properly be imputed to instances where the defendant acts out of insensitivity to the interests of other people, and not merely out of an intellectual failure to grasp them» ${ }^{8}$.

A notion of criminal negligence impregnated, therefore, by subjectivity, that contains a basis of morality ${ }^{9}$. It could also be defined as an intuitive conception of the mental state, that must be "felt" (by the jury), rather than analyzed.

To the Italian doctrine, which has a long tradition of commitment to the mythvalue of legality, this idea might seem contrary to the defense of civil rights: yet in the U.S. this is considered the best indication upon which to trace the boundary of criminal relevance, of negligence and other notions.

\footnotetext{
${ }^{5}$ In a critical sense, see FLETCHER, Dogmas of the Model Penal Code, in 2 Buffalo Criminal Law Review, 3 (1998); ID, Basic Concepts of Criminal Law, Oxford, 1997, chap. 8; SIMONS, Dimensions of Negligence in Criminal and Tort Law, 3 Theoretical Inq. L., 305 (2002); EDGAR, Mens Rea, in Encyclopedia of Crime and Justice, 1037 (1983): "The terms that positively indicate the mens rea, basic, are fictions. The law deals with probative problems related to the mental states through the use of presumptions".

${ }^{6}$ BLOCH-McMUNIGAL, paper cited, p. 211.

${ }^{7}$ LOEWY, Criminal Law, MN, 2003, 39.

${ }^{8}$ Comment to Model Penal Code, $\$ 2.02$, Negligence.

${ }^{9}$ HUSAK \& SINGER, Of Innocence and Innocents: The Supreme Court and Mens Rea Since Herbert Packer, 2 Buffalo Criminal Law Review, 860 (1999).
} 
In a sense it is the "price" that the Anglo-Saxon system pays for a concept of negligence exclusive to the criminal system. A concept lacking in certain analytical parameters for establishing the notion, and above all the civil/penal shift, the "something extra" of criminal negligence appears to be resolved intuitively, "self-evident" to the criminal system itself. A system that definitively entrusts laymen to evaluate the criminal relevance of negligence.

What is the approach of U.S. law regarding civil negligence?

In the Second Reformulation of US Civil Law (Restatement of Torts, Second), the basic structure of civil negligence includes minor negligence. Civil negligence is defined in plainer terms than criminal negligence: "Negligence is conduct that falls below the standard established by law for the protection of others against unreasonable risk of harm. It does not include reckless conduct that disregards the interests of others".

It is interesting to note how the most recurring question in U.S. law manuals is, in inverted terms, speculation on a question that is increasingly widespread among Italian criminal law scholars. Italian scholars focus on the question of legitimacy and/or opportunity to adjust restrictive terms regarding the concept of criminal negligence, to eventually cover cases of gross negligence (whether conscious or not). American criminal law scholars, on the contrary, start from the limit of grossness (the already existent de iure), consider whether it is desirable that in different areas of substantive law the concept of mental states becomes uniform, thus arriving to align criminal and civil negligence ${ }^{10}$.

II. (continued) ... the distribution of omissive and negligent crimes, between individualistic liberalism, solidaristic statism and communitarianism; between the reactive State and the active State; between the individual model of property and the collective/communitarian model of inalienability; between "privatized" and "socialised" healthcare.

The role of criminal law in Italy cannot be assessed outside of the overall legal, political and cultural context.

To quote the Spanish scholar Silva Sanchez «The pretension to harmonize a maximum State and a minimum criminal law constitutes a contradiction in terms. For a single reason: insecurity about the perception of the services [...] directly or indirectly coming from the State leads to the exploitation of criminal law to guarantee (at least so it is claimed) them» ${ }^{11}$.

From a political and cultural point of view, the "maximum State" (to resume the expression of Silva Sanchez) seems connected, in Italy (and perhaps in continental Europe in general), to the greater trust traditionally placed in regulatory interventions of the State. The idea is that "institutional public regulation is superior in allocating optimal well-being

\footnotetext{
${ }^{10}$ Cfr. BLOCH-McMUNIGAL, paper cit., 318.

${ }^{11}$ SILVA SANCHEZ, La expansión del derecho penal Aspectos de la política criminal en las sociedades postindustriales, Madrid, 2011, in particular chap. 4.
} 
when compared to the "market". In other words, the developement of political-normative regulations produces superior desirable results on well-being than the commitment of the same well-being to uncontrolled forces within civil society"12.

Given these premises, in States (like Italy) where criminal law traditionally carries out such a role, an invitation to prudence seems due. As when it is suggested to decisivly "trim" many branches off a criminal law system that is perceived, almost presumptively, as suffocating and primitive. The objective is to "transplant" concepts, models, ideas and systematic constructions applied by another legal system actualised in a different country ${ }^{13}$.

In other words, a cure worse than the disease, if the much lauded elimination/reduction of some parts of the criminal "penal apparatus", despite its flaws, are not compensated by the introduction of adequate forms of substitutive control.

The principle of criminal law as a last resort (extrema ratio), which certainly expresses a noble request, can simultaneously represent a "magic bullet" that easily lends itself to indistinct and uncontrolled use. A principle whose insignia seems obvious to recognise, but that still includes too many unknown "variables". Primarily "the difficulty or the impossibility of precisely defining the need for criminal sanctions and the sufficiency of non-criminal alternatives, with respective degrees of effectiveness, given the infeasibility of previous tests, shortcomings, discords and the doubtful value of unestimatable empirical findings" ${ }^{14}$.

Beyond the hypercritical attempts to "demolish without reconstructing" and the preconceived defense of existing laws, it must be acknowledged - with F. Mantovani that the main challenge of current criminal law seems to be its "crisis of solitude". In the face of various social problems, criminal law is often left not as the last (extrema) resort, but as the sole resort (ratio) in an attempt to "keep the peace"15.

This also seems to be the case of medical responsibility. In the abscence of valid and alternative systems of control and socio-cultural counterforces, is it really feasible or desirable that criminal law recedes from a "hard line" defense of life, well-being and personal safety? ${ }^{16}$

\footnotetext{
12 SGUBBI, Il reato come rischio sociale, Bologna, 1990, 17.

${ }^{13}$ To use an engineering metaphor, a "cogwheel" that spins in a given apparatus of rules could turne out to be not as functional in another one.

${ }^{14}$ MANTOVANI, La "perenne crisi" e la "perenne vitalità" della pena. E la "crisi di solitudine" del diritto penale, in Studi in onore di Giorgio Marinucci, Milan, 2006, 1181. The author speaks also of "crisis of the crisis", in the sense that "the crisis of the criminal law is accompanied by the crisis of the proposed alternative models to the criminal law itself".

${ }^{15}$ ID, paper cit., 1202.

${ }^{16}$ As MANTOVANI teaches (paper cit.), the modern history of the criminal law consists precisely in a (never outdated) dialectic between legitimization, de-legitimization and re-legitimation: attempt to remove such dialectic contrapositions, from this point of view, represents only a sterile "intellectualism", a "reductionism" that smacks of an idealized "illuminism out of time and space". Even FIANDACA-MUSCO agree that $<<$ the models of legitimation developed by scholars are influenced [...] by an "idealistic"
} 
It seems to confirm the need for a comparison between European and U.S. law, not only from a synchronic perspective but also from a diachronic perspective: i.e. taking into account not only the current state of the legal systems, but also their historical evolution and, last but not least, the different factors that influence the current systemic realities, along with their prospects for future evolution.

Once models, rules, languages and different legal forms are placed in the proper historical-political and cultural dimension, it will perhaps be possible to identify the ideas and inspirations that can be exported from one system to another, as well as the pitfalls to be avoided.

While continuing the reconstruction of factors around which the various regulatory systems rotate, it is possible to note how, from a cultural point of view, in Anglo-Saxon countries the dominant socio-political tradition is liberalism. More than a well-defined school of thought, liberalism is an intellectual and moral attitude whose "founding fathers" are the English philosophers Bentham and J.S. Mill (the latter a student of the first). Liberalism strongly emphasizes the value of individual freedom and only recognizes to the State the task of refraining from interventions that sacrifice or inhibit this freedom ${ }^{17}$. To the point that, according to one of the most recent and extreme formulations of liberalism, the only morally legitimate form of a State, as not to be detrimental to individual rights, would be the minimum State. A State which radically limits its own interference into the sphere of the individual (think of Nozick, for example, although the liberal school obviously knows more moderate positions such as Rawls or Berlin).

In the U.S., liberalism is typically associated with individualism: a term introduced by Tocqueville to indicate, in general, an attitude that promotes the individual with respect to the social whole ${ }^{18}$.

approach, being often based on points of view and concerns that are quite foreign or indifferent to ordinary people. And there is risk that this split is accentuated precisely in an historical contingency such as the one we are experiencing "(Perdita di legittimazione del diritto penale?, in Riv. it. dir. proc. pen., 1994, 25).

17 MATTEUCCI, item Liberalismo, in Dizionario di politica, directed by Bobbio-Matteucci-Paquino, Turin, 1990, 566. From the field of the production and the exchange to that of law, the fundamental principle with which the Anglo-American reflections still today confront themselves, also in terms of space attributable to the penalty, is that, classic, of self-protection, formulated by Mill in his most famous work, On Liberty (1859): for a reconstruction of the Anglo-American socio-philosophical and criminal doctrine, in its focus on the concept of "harm to others", see FORTI, Per una discussione sui limiti morali del diritto penale, tra visioni "liberali" e paternalismi giuridici, in Studi in onore di Giorgio Marinucci, eds. Dolcini and Paliero, vol. I, Milan, 2006, 308; FRANCOLINI, L'harm principle nel diritto angloamericano nella concezione di Joel Feinberg, in Riv. it. dir. proc. pen., 2008, 276; as well as FIANDACA-FRANCOLINI (eds.), Sulla legittimazione del diritto penale. Culture continentale e anglo-americana a confronto, Turin, 2008.

18 The term individualism, if today it is used in the socio-philosophical debate as a "neutral" term from an evaluative point of view, represents a position that, especially at the political level, in Europe has been (and still continues to be) commonly criticized as "self-interested, anti-social, anti-solidaristic»: see FABBRINI, L'America e i suoi critici. Vizi e virtù dell'iperpotenza democratica, Bologna, 2005, 135. In general (according to FABBRINI, paper cit., 251; BENCIVENGA, Le due americhe. Perchè amiamo e perché detestiamo gli Usa, Milan, 2006, 25), American liberalism remains basically a method, which presupposes the recognition of the interests of all classes, sees the market as the privileged location of the individual 
Regarding individualism, the comparative law scholar Damaška coined the notion of the reactive State, whose "instruments must liberate the spontaneous forces of social self-management. The State knows no notions of interest distinct from social and individual (private) interests. There are no problems typical to the State, only social and individual problems"19. According to Damaška, it is natural that, in the Anglo-American system, where individual preferences are sovereign, the preferred normative instruments are various types of agreements, contracts and pacts [...] Therefore a wide range of suspendable rules characterizes the legal culture of the Reactive State: absolute orders and prohibitions are anomalies. [...] the law facilitates and supports the self-regulation of the members of the civil society by creating "negotiating tools" for conventions between the citizens" 20 . There is clear reference to the "centrality of the contractual method".

In the active State, clearly defined as opposite to the reactive State, we see that «the dominant image of the law, absolutely distant from contractual notions, is that of a provisional State [...] Unlike the law of the reactive State, whose effort it is to define forms that allow the free pursuit of chosen objectives, the active law is imperative, sometimes even authoritarian: it tells the citizens what to do and how to behave» ${ }^{21}$.

Among the duties of the citizen, solidarity in particular which is traditionally relegated to a moral duty in other legal systems (so-called Good Samaritan Law), soars in Italy as a principle representing the Republican Constitution. That is, alongside the recognition of fundamental human rights it is explicitly requested that citizens assume the "fulfillment of mandatory duties of political, economic and social solidarity" (Art. 2 of the Constitution).

In Italy, criminal law appoints itself as the primary mediator between the individual moment - the guarantee of personal freedom - and the social moment - the guarantee of substantial equality and / or solidarity.

Criminal law, as an instrument used as a liberal basis for the protection of inviolable rights and freedoms, therefore also becomes a social instrument for the

\footnotetext{
freedom, and the State as a simple "guarantor" (and competition as a democratic factor preventing the accumulation of power). In the old Continent, instead, for "historical" or "geographical" reasons (closed space and limited resources), liberal thought easily transforms into ideology, favorable only to the dominant social classes. Hence, the need to contrast liberal thought with a strong "dialectic" element, such as the "collectivistic" (or corporatist, or organicist) idea: the market thus becomes not only "guaranteed", or "regulated" by the State, but "socialised" or "statalized"; and the competition between values and interests, viewed with suspicion, in continental Europe makes way for the hierarchical definition of that values and interests. In short: in Europe a society that is generally less dynamic is born, yet more egalitarian, a more participated but also more paternalistic democracy: the so called social State (subject to the rule of law), or solidaristic State (which in Italy finds its consecration in Art. 2, subsection 2, Constitution). In European political thought, in any case, the limits of American liberal individualism are highlighted, from left wing movement in the name of social solidarity, from right wing movement in the name of the organic State.

${ }^{19}$ DAMAŠKA, The Faces of Justice and State Authority, New Haven, 1986, ed. in Italy by il Mulino, pag. 136.

${ }^{20}$ ID, paper cit., 139.

${ }^{21}$ ID., paper cit., 149
} 
protection of collective interests and the implementation of the objectives of the solidaristic State ${ }^{22}$.

In light of the ever-increasing tasks attributed to the State, law is oriented not only in a prohibitive but also promotional sense. Particularly in criminal law, it is not only repressive (of prohibitions), but also constrictive (of commands).

It is within this broader political and cultural perspective that the traditionally larger quantitative extension of omissive and negligent crimes in continental Europe should be framed.

To quote the well-known American scholar Coffee: "In general, civil law sets a price, while criminal law prohibits"23.

If everything has a price, everything can become property of the most powerful, as Roxin teaches, warning against the growing temptation to favor a "privatistic and autonomous composition of the conflict". "Faced with the withdrawal of the State from the area of injury of significant assets - the author writes clearly- there is indeed risk that not the right but the stronger wins, and that legal peace is threatened more by the play of opposed influences, than by the crime itself" 24 .

At this point, a doubt may arise: Is the U.S. system, in creating a mostly civil protection regarding negligent offences, therefore less devoted to the fundamental values of life and personal safety? How to interpret the differences from the point of view of comparative law?

In reality, with regards to the value of life and personal safety, civil protection does not necessarily mean less protection. It primarily means a different type of

\footnotetext{
${ }^{22}$ About criminal law of freedom, see the model set by MANTOVANI F., Diritto penale. Parte Generale, Padua, 1992, 21; compare with FORTI, paper cit., 331: «more or less latently and consciously, this branch of the system (due to the human bearing of its coercive means) expresses a certain "communitarian" vision, inasmuch as it endorses a conception of the person, however disguised under a patina of values' neutrality and liberal (indeed) self-restraint. As a matter of fact, punishment is something that evokes the whole, the totality, even of those to whom it is inflicted. A totality that arises from its complexity as social institution". V. DAMAŠKA, paper cit., 158, 162: "Many Europeans, looking at England and America through the prism of their experience, were surprised by the relatively modest function performed by the State in the management of social affairs. While the legislators of the Continent were continually expanding the tasks of the State [...] it seemed that in England and America, still recently, they relied on a much more important measure, on the private or "voluntary" action for the satisfaction of social needs. The foreigners were surprised by the functioning of this "minimalist Statism", and proposed a series of theories to explain the mystery. A theory that has gained widespread acceptance attributes the relatively minor importance of the State in the Anglo-Saxon countries to the claimed better success of the capitalist market in these countries; the more pervasive and effective the mechanism of the market, it is said, the lower the need for direct intervention by the State; power can be exercised above all in the economic-social sphere, and the social apparatus can often be circumvented".

${ }^{23}$ COFFEE, Does "Unlawful" Mean "Criminal"?: Reflections on the Disappearing Tort/Crime Distinction in American Law, 71 B.U.L. Rev. 194 (1991).

${ }^{24}$ ROXIN, Risarcimento del danno e fini della pena, in Riv. it. dir. proc. pen., 1987, 12.
} 
protection, which can still be "balanced", no less effective and / or satisfactory than a criminal one. As a matter of fact, protecting assets in different areas of civil law means putting them under the spotlight and enhancing different characteristics of the assets themselves. Considered on a case by case basis with ever increasing importance and deservance of protection, allowing precedence over other charateristics. Regarding life, for example, it can mean protecting it as an economic entity, rather than only recognizing its legal-ethical-social value, and it is not given that the first form of protection necessarily produces a lower efficacy than the second.

For a correct contextualization of technical legal specificities, it is necessary to keep in mind the different approach to the subject-body relationship held in the U.S.A. and in European law and culture.

In the U.S.A., the subject-body relationship appears, mainly, to fall under a typically individual and dominical logic (the so-called property model ${ }^{25}$ ), proved by the extension to different parts of the body (organs and tissues) of negotiating schemes aimed to allow its circulation for payment (eg for the location of gametes, or the disposition of blood $)^{26}$.

The option for criminal protection, in a country such as Italy, must be contextualised within the broader cultural and legal framework of a subject-body relationship different from that characterizing the U.S. experience. Continuing the comparison, it can be said that, not only in Italy, but also in other continental European countries, the technique or model of protection mainly followed is that of inalienability (unavailability).

Personal assets, described as legal objects in Italian law, and in particular in the Italian criminal code, seem to be characterized by an important role assumed in a social dimension.

A dimension that is initially connected to the collectivistic-organistic utilitarianism, which in the framework of the authoritarian State (1930) saw human beings as an entity exploitable for public interests (and human life also as a colletive interest ${ }^{27}$ ). A dimension later connected to constitutional personalism, which in the

\footnotetext{
${ }^{25}$ About the rules of responsibility and ownership, which corresponds to a medium-low State intervention, among the first fundamental contributions of economic analysis of law see CALABRESI-MELAMED, Property Rules, Liability Rules, and Inalienability. One View From the Cathedral, 85 Harvard Law Rev. 1089 (1972). More recently, RAO, Property, Privacy and the Human Body, 80 B.U.L. Rew. 359 (2000); RODOTÀ, La vita e le regole. Tra diritto e non diritto, Milan, 2006, 73 ss.; ID, Ipotesi sul corpo "giuridificato", in Tecnologie e diritti, Bologna, 1995, 180; similar setting in RESTA - ZENO ZENCOVICH, Informazione, consenso e responsabilità nei trapianti da vivente: prospettive nazionali $e$ comunitarie, in Riv. it. med. leg., 2003, 969.

${ }^{26}$ At a theoretical level, an authoritative support for such construction certainly comes from the school of "economic analysis of law": see RODOTÀ, last paper cited, p. 196.

${ }^{27}$ Not only in Italy, but also in other continental European countries, the technique or model of protection of life and personal safety mainly followed is the inalienability model, historically imposed in accordance with the policy objectives of an authoritarian State (code Rocco, 1930), where the individual interests were
} 
context of the social State of law (1948) promotes instead the development / improvement of the social system, substantial equality (Article 3, paragraph II, Cost.), and freedom itself (now interpreted as personal, or positive freedom), through the assumption of new and broader tasks assigned to the State, as well as in the criminal field.

The extension to omissive and negligent crimes certainly falls cleanly into this new and broader perspective of protection of the human person.

The contemporary historical-political framework favors the extension of concepts of omission and negligence (even medical) that are criminally relevant into the synergy realized between: a] intervention of the welfare State in ever wider spheres of a citizens life (from health care to work relations, etc.); b] increasing technological progress and mechanization: the increased potential for harm in social life is faced with the creation of an ever-increasing number of precautionary rules.

This development is incessant (of "techniques", of social function, of the State, of criminal law) and characterizes the Italian experience throughout the twentieth century. Specifically in the field of health, this development arrives under the banner of "socialization" that promotes good-health as fundamental not only to individual but also to so collective interests (Art. 32 of the Constitution).

This c.d. socialization of interests (typical of the Italian experience ${ }^{28}$ ) with reference to health, offers a further possible key to understanding the different approach to medical responsibility seen in Italy, compared to the U.S..

While for a prevalently privatized healthcare system, like the U.S. system, it is natural to adapt mechanisms that are purely geared toward civil protection. For a coutry like Italy, where we find a greater state intervention regarding the protection of health,

rigidly dependent on collective ones (so-called collectivization of the interests). Criminal protection appeared then as the most suitable to defend assets, such as life and the personal safety, considered not of exclusive individual relevance, but mainly related to the superior State interest.

To go back even further, already at the dawn of the distinction between voluntary and involuntary homicide (as clarified in Roman criminal law), manslaughter perpetrated without occidendi animus, although not always sanctioned (in the royal and decemviral laws) with capital punishment, like voluntary killing involved the obligation of an expiatory sacrifice, to be carried out in public assembly: the death of a citizen (free, of course) was considered to involve anyway the interest of the res publica, upsetting "gods' peace" (pax deorum): v. SANTALUCIA, item Omicidio (dir. rom.), in Enc. dir., XXIX, Milan, 1969, 885.

Purified of religious encrustations, the justifying nucleus of the thesis that killing offends a collective good, before an individual one, ends up clearly outlined in the words of one major exponent of the Positive School, E. Ferri. "Not only the individual, but also human society has a supreme goal to be reached, for which its existence is therefore necessary, and as this results precisely from the existence of each member, so then Society has the right that, preserving his own, they preserve their existence ": see FERRI, L'omicidiosuicidio, Turin, 1925, 488. In the same sense, NUVOLONE, Diritto penale. I delitti contro il patrimonio e contro la persona, Milan, 1964, 207; GRANATA, L'omicidio nel diritto penale, Rome, 1960, 12; VANNINI, Delitti contro la vita, Milan, 1958, 5. For the latter author, the good of life from the subjective point of view turns into a dual interest: individual, as supreme good of every human being, and ethicalpolitical, "as demographic interest, as a condition of life and development of the social aggregate, as condition of moral and material force of a politically organized people".

${ }^{28}$ SGUBBI, paper cited, 34. 
interpreted as a public good, it is instead reasonably accompanied by a growing recourse to criminal law.

The fact remains that, from a "functional" point of view, the two legal experiences have evolved in parallel. In both we indeed find «the lower courts and even more the Supreme Court imparted to the "living law" on the issue of medical responsibility an evolutionary movement in successive phases progressively shifting to protect the rights of the patient, and simultaneously less protection of the rights of the physicians» ${ }^{29}$. This trend favors the rights of the patient (although not immune from periodic reexamination), common to the two systems and developed throughout the twentieth century according to the particular characteristics and "systematic preferences".

When the evolution of malpractice is approached from a general viewpoint, in a broad diachronic perspective, the following parallelism seems to be established: A trend for "privatization" in American healthcare is matched by a revolution in rights, in favor of the patient, carried out in the field of tort law; while a prevalent "socialization" of Italian healthcare is accompanied by a parallel prevalent escalation of criminal responsibility.

In order to identify possible factors that could explain why in the U.S. negligence traditionally plays a greater role in the field of torts (civil responsibility) rather than in the criminal field, it is useful to reflect on the birth and development of negligence lawsuits in American law.

Already in the mid-nineteenth century - according to Friedman's reconstruction the tort of negligence begins to impose itself on other civil lawsuits and actions ${ }^{30}$.

The scholars who analyzed the origins, development and functions of the tort system (legal form practically non-existent before the nineteenth century) have found that, contrary to its more recent evolution (which makes it the emblem of the individual rights movement against the oppression of "stronger powers"), this institution initially intended to encourage, or at least not hinder, the growth of the young business world ${ }^{31}$.

Civil law, more dynamic and evolved than penal law, appeared the most flexible instrument to accompany - while avoiding rigidities and overly severe disciplines - the development of a nation which appeared on the world stage making economic freedom

\footnotetext{
${ }^{29}$ FIORI, Medicina legale della responsabilità medica, Milan, 1999, 237.

${ }^{30}$ FRIEDMAN, History of American Law, 1985, edited in Italy by Giuffrè, pag. 301: «The real explosion of the tort law and negligence, in particular, must be traced back to the industrial revolution, the era of engines and the machines. Indeed, this field of law mainly deals with personal injuries. In a pre-industrial society there are few cases of personal injury, except as a result of violence or beatings». On the explosion of (civil) liability in the American law during the twentieth century, see also ID., American Law in the 20th Century, New Haven - London, 2002, chap. II.

${ }^{31}$ FRIEDMAN, History, paper cit.., 475 following.
} 
its strength and strong point. Many institutions and civil concepts were therefore born, and initially used "for use and consumption" by business and companies ${ }^{32}$.

Only at the beginning of the twentieth century did tort law, which until then had tenaciously defended the economic interests of the productive classes for a sort of "heterogenesis of the ends", begin to undergo more and more consistent pushes in the opposite direction: The direction of protecting those who had become "victims" of progress.

Innovations, such as the doctrine of the res ipsa loquitur ${ }^{33}$, the extension of the notion of responsibility and the increase of damages payable to the plaintiff, developed in the 70s of the last century, entered the malpractice area and began to hurt the interests of social groups traditionally considered "protected", such as physicians, dentists, nurses and hospitals in general. The foundations were then laid for the explosion of responsibility for which nowadays a court summons represents an almost inevitable event in the career of a North-American health professional ${ }^{34}$.

The point to highlight here, while reconstructing origins and influential factors, is that in the U.S. the primary role of tort law (particularly, the tort of negligence), is its ability to become common in a more rapid and articulated way even compared to the English motherland. This is precisely because the tort of negligence constituted (and still contitutes) a more agile and dynamic tool to govern responsibilities in a society that from an "economic" point of view became strong very rapidly and from a "technical" point of view became more complex ${ }^{35}$.

And what functions did criminal law perform in the U.S. system?

Born as deeply imbued with the concept of sin, and collected in laws often with a "strong Mosaic flavour" ${ }^{36}$, this branch of the legal system, from the colonial period to the end of the nineteenth century, remained little developed. Since criminal law is, as a matter of fact, the primary instrument in the hands of authorities to exercise power over the

\footnotetext{
32 On the insistence of the American legal theory of post civil war in limiting both the responsibility and the measure of the damages, v. GILMORE, The Ages of American Law, 1977, edited in Italy by Giuffrè, pag. 87; compare with FRIEDMAN, paper cit., 481.

${ }^{33}$ On the historical evolution of malpractice, see ROTHMAN, Strangers at the Bedside. A History of the Law and Bioethics Transformed Medical Decision Making, New York, 2003, 127 following; CAVE BONDI-CIALLELLA, Medical negligence: inquadramento storico della responsabilità professionale nel diritto americano, in Iura Medica, 1995, 22 (res ipsa loquitur is the civil thesis based on a presumption of negligence created by a circumstantial evidence).

${ }^{34}$ The explosion of responsibility had such a force that (as often happens) it has finally produced an "oscillation" in the opposite direction, a counterrevolution (FRIEDMAN), proved by the introduction, in more than thirty States, of rigid limitations (caps) on the amount of the compensations, especially with regard to non-economic and so-called "punitive" damages: see STUDDERT-MELLO-BRENNAN, Health Policy Review, in ANDERSON (Ed.), Medical Malpractice. A Physician's Sourcebook, Totowa, 2005, 237; FRIEDMAN, American Law, paper cit., 539.

35 ALPA, Presentation of FRIEDMAN, Storia, paper cit., XXIV. Compare with CAVE BONDICIALLELLA, paper cit., 11

${ }^{36}$ FRIEDMAN, Storia, paper cit., 67. Compare with ID., American Law, paper cit., 365.
} 
citizens, in a country where, compared to England, "the degree of the connection between the rulers and the ruled was greater [... ] this led to a considerable laxity in the effective use of criminal measures" 37 .

Around 1900, the social investment in the fight against crime increased, with an aim to contrast mostly violent crimes (which, especially in the cities, were no longer tolerable by an industrial society, now characterized by close relations). As happened with the tort, crime was initially considered "bad for business", and was consequently repressed ${ }^{38}$. So much so that it was also possible to configure responsibility for unvoluntary crimes, but only if directed against property. A good - property - which, in order to protect the wealth of the country, received in the criminal area a much stronger protection than that of the person.

With regard to the dimension of protection of property in the framework just outlined, personal property and in particular health, began to evolve from the standpoint of administrative organization of health services, towards a purely privatistic dimension: the dimension that still mainly characterizes them today.

III. "Access to justice", paths and outcomes: contingent fee in tort area and criminal justice as "free legal aid"; "preponderance of evidence" and "beyond reasonable doubt"; compensation for a few people and symbolic criminal convictions.

To evaluate the functionality of the different forms of protection it is necessary to innitially take into consideration the conditions of access to justice, then the different paths and trial "turning points", with particular attention to the key element of causality, and finally the outcomes of the different models.

One factor of American specificity, with regards to the tort of malpractice, is the contingency fee. This condition guarantees legal aid and specialized consulting services to clients without any advance payment, and only in the case of compensation the fee and reimbursement of expenses are recognised to the professionals, generally in the amount of $1 / 3$ of the final reimbursement ${ }^{39}$.

Does the contingent fee make access to justice easier for the victims of malpractice?

According to data on the US system, in the context of adverse events due to negligence (therefore, of potentially "valid" claims), only about $2 \%$ (even $1.2 \%$, according to a study conducted in a Chicago hospital ${ }^{40}$ ) are actually filed as judicial

\footnotetext{
${ }^{37}$ FRIEDMAN, Storia, paper cit., 285.

${ }^{38}$ FRIEDMAN, last paper cit., 606.

${ }^{39}$ GREMBI, Una riflessione tra economia e diritto sulla malpractice medica: i casi di Stati Uniti e Italia, in Mercato, concorrenza, regole, 2005, 459.

${ }^{40}$ HYMAN-SILVER, Medical Malpractice Litigation and Tort Reform: It's the Incentives, Stupid, 59 Vand. L. Rev. 1091 (2006).
} 
proceedings. It is the phenomenon of so called under-claiming (patients entitled to compensation generally do not sue). The overwhelming majority of patients suffering medical damage due to negligence, for various reasons, do not sue $(98 \%)^{41}$.

The contingent fee seems to advantage filing only the actions with the highest "bet", in terms of potential refundable damages.

The total number of actions brought about each year throughout the nation is around 85.000, and in general, on this final figure, under-claiming is far more prevalent than over-claiming (patients who sue but do not deserve compensation) ${ }^{42}$.

Assuming that, as the most recent research seems to show, in cases of malpractice a small minority of the injured sue (2\% in the US, $16 \%$ in Italy, according to the Tribunal for the Rights of the Sick ${ }^{43}$ ), it may seem paradoxical or provocative that some authors even say that "the problem of medical negligence is that not enough people sue"44.

For a long time now the most authoritative doctrine has been committed to "bringing our attention to the law, or in any case the expectation by flesh and blood victims of crime to be included, as co-protagonists, in the legal and judicial circuit" ${ }^{45}$.

Obviously for the victim, "being included in the legal system" means, above all, not having the economic burden of providing resources necessary to file an action.

It is necessary to consider that to bring about a lawsuit for malpractice, considerable resources are needed. Resources not only in economic terms, but also in terms of time; not to mention that the long, inefficient and expensive procedure of tort

\footnotetext{
${ }^{41}$ CHESSICK-ROBINSON, Medical Negligence Litigation is Not the Problem, 26 N. Ill. U. L. Rev. 566 (2005), which underline the very high costs (from \$ 35.000 to \$50.000) necessary to bring a civil suit for malpractice; according to STUDDERT - BRENNAN - THOMAS, Beyond Dead Reckoning: Measures of Medical Injury Burden, Malpractice Litigation, and Alternative Compensation Models from Utah and Colorado, 33 Ind. L. Rev. 1643 (2000), one possible reason is that the damages are too small to justify a lawsuit; another possible reason is that the lawyers, who typically work on contingency fees, wish to file action only for "attractive" clients (i.e. victims easy to pity, with causes for serious damages); alternatively, some people are simply not litigious by nature. On why so many "real" victims do not sue, see also HYMAN-SILVER, Medical Malpractice Litigation and Tort Reform: It's the Incentives, Stupid, 59 Vand. L. Rev. 1113 (2006): «the malpractice system is expensive, burdensome, and slow. To become a plaintiff, a patient may have to terminate an existing relationship with a health care provider and find a new source of treatment. A patient may fear being "blacklisted" that is, being refused treatment by other physicians or providers who steer clear of patients known to sue».

42 HYMAN-SILVER, Medical Malpractice Litigation and Tort Reform: It's the Incentives, Stupid, 59 Vand. L. Rev. 1089, 1092 (2006). Further on, the authors also analyze the reasons why patients sue: «The incentive to sue depends on the severity of the injury, out-of-pocket expenses, and the extent of the patient's irritation with the provider».

${ }^{43}$ According to the data of the Italian Tribunal for the Rights of the Sick, reported in the article Badly treated by the $50 \%$ of the operators, Corriere della Sera, 17/4/2007, "in 84\% of the cases of suspected error reported by citizens no medical and legal advice starts".

${ }^{44}$ MULCAHY, Threatening Behaviour? The Challenge posed by Medical Negligence Claims, in FREEMAN \& LEWIS, Law and Medicine, New York, 2000, 102.

${ }^{45}$ FIANDACA, Perché punire e come punire?, typescript, 1.
} 
transforms most of the resources (54\%) into profits for lawyers and technical experts, in addition to insurance and administrative costs ${ }^{46}$.

Less than half - if all goes well - directly favors the injured.

From this standpoint, it is evident that criminal law potentially offers some practical advantages if compared to other forms of protection, and in particular if compared to tort law. In the event that the complaint is likely valid, in Italy the public prosecutor then orders a publicly funded consultation. The patient can use this consultation even in the event of a civil trial.

That public prosecution can be interpreted as the cheapest way to obtain justice is not new, even in the U.S. ${ }^{47}$. Already Packer, in his famous work The Limits of Criminal Sanction, speaking of latent functions of criminal law, noted that "the service [of the public prosecutor] is very satisfactory to the plaintiff, since he obtains free legal aid" 48 .

At the same time it must be kept in mind that there are risks of manipulation, and potential losses undergone by the public prosecutor's function: «it is a burden for the public prosecutor's office to be called to carry out functions essentially of tort law, and equally important, there is always the possibility of injustice and abuse, due to the coercive effect of the threat of a trial against a person who is not normally represented by a lawyer».

But the only plausible alternative - to quote Packer again - is "to provide adequate legal aid to the majority of individuals who can not afford legal services at the current price".

Continuing with the comparison between the different process paths and trial "junctions", one of the main differences between tort and criminal law seems to concern the element of causality.

Given that satisfactory and punitive interests are both present in the victim (either the injured party in the civil realm or the plaintiff in criminal law), and given that these interests, although variously emphasised, are not easily dissociable, nor separately "weighable" in different trials (civil and criminal), the variation between methodologies for ascertaining civil causality and criminal causality depends on the position of the accused in the criminal trial, compared to the civil defendant.

\footnotetext{
${ }^{46}$ BARRINGER, A New Prescription for America's Medical Liability System, 9 J. Health Care L. \& Policy 241 (2006). On the low efficiency of the medical malpractice system, see MELLO-STUDDERT, The Medical Malpractice System: Structure and Performance, in SAGE-KERSH (Eds.), Medical Malpractice and the U.S. Health Care System, New York, 2006, 11.

${ }^{47}$ On this point, with specific reference to the Spanish experience, see RODRIGUEZ VAZQUEZ, Doctors in Spanish Criminal Law: Medical Responsability for Death and Injuries caused by Negligence in PresentDay Spain, in 25 Medicine and Law 411(2006).

${ }^{48}$ PACKER, The Limits of Criminal Sanctions, Stanford, 1968, Italian edition by Giuffrè, 1978, 304.
} 
The reflections on the "transcendental" values and the immense scope (to resume the expressions of the American judges) brought into play by the accused, and on the accused's disadvantaged position, appears central in U.S. case law. On this basis, the construction of a probative standard for criminal trials (and for criminal causality) which is far «more stringent» than the civil one, has been initiated: bifurcation / differentiation of the category-causality, criminal versus civil, subsequently imported in Italy, with the leading sentence of the Italian Supreme Court, civil joint session, 11/1/2008 ${ }^{49}$.

Also on this basis, given that the etiological development "the trial is substance", a different substantial status of causality is also founded (the thesis of causality becoming a trial element is now becoming established, in the sense that upon the configuration of this category of substantive criminal law, the method of its evidential scrutiny has a decisive influence) ${ }^{50}$.

In U.S. law, where the distinction between criminal causality / "beyond any reasonable doubt" and civil causality / "more probable than not" has arisen, the different

\footnotetext{
${ }^{49}$ Italian Supreme Court, civil joint session, 11/1/2008, n. 576, V. c. USL 42 Napoli (about responsibility for damage from transfusions with infected blood), in Cass. pen., 2009, 69, with a note of BLAIOTTA, Causalità e colpa: diritto penale e diritto civile si confrontano.

${ }^{50}$ So, quoting the famous "Franzese" sentence of the Italian Supreme Court, criminal joint session, 10/7/2002 (in Foro it., 2002, II, 598, with a note of DI GIOVINE, La causalità omissiva in campo medicochirurgico al vaglio delle sezioni unite; in Dir. pen. e proc., 2003 , 50, with a note of DI MARTINO, Il nesso causale attivato da condotte omissive tra probabilità, certezza e accertamento; in Riv. it. med. leg., 2002, 1605, with a note of FIORI - LA MONACA - ALBERTACCI, Le Sezioni unite penali della Cassazione riaffermano l'esigenza di elevata probabilità logica del nesso causale nelle condotte mediche omissive: ma nel contempo confermano, pur dichiarando prescritto il reato, la responsabiità del medico in un caso di colpa e nesso causale poco probabili): «the definition of the concept of criminal causality significantly depends on trial scrutiny, which remains decisive for the decoding, in effectual terms, of the causal development related to the single event, especially in the presence of complex phenomena of "multiple causality", linked to the modern advancement of activities». In doctrine, on the criminal categories becoming trial elements, a far-reaching phenomenon in which "criminal law is adapting, in its own structures, according to procedural forms", see PADOVANI, Il crepuscolo della legalità nel processo penale. Riflessioni antistoriche sulle dimensioni processuali della legalità penale, in Ind. pen., 1999, 541. On the impact of proof in defining the juridical concept of causality, see DONINI, La causalità omissiva $e$ l'imputazione per l'aumento del rischio. Significato teorico e pratico delle tendenze attuali in tema di accertamenti eziologici probabilistici e decorsi causali ipotetici, in Riv. it. dir. proc. pen., 1999, 82; MARINUCCI, Il diritto penale messo in discussione, in Riv. it. dir. proc. pen., 2002, 1041; DI GIOVINE, La causalità omissiva, cit., 612; PIEMONTESE, Le problematiche della causalità omissiva: tendenze emergenti e modelli prasseologici, in Scritti in onore di Antonio Cristiani, Torino, 2001, 603; FIORE, La teoria generale del reato alla prova del processo, Naples, 2007, 91 following.; in a critical sense, STELLA, L'allergia alle prove della causalità individuale, in Riv. it. dir. proc. pen., 2004, 380, who strongly emphasizes the danger that case law proceeds «in the name of an ill-concealed aspiration to start off an authentic 'evidential function' of the substantial criminal law». In the German doctrine, on the difficult relations between "concept" and "proof" of causality, compare with VOLK, Sistema penale e criminalità economica, Naples, 1998, 89: "Our distinction between theory and praxis finds its correspondence in the different systems of substantive and procedural law. [...] We proceed, in relation to the question of law, in a different way from the question of fact. This works very well until only the "law" is relevant in the first sector and only the "experience" in the second. But if you need rules of experience already for the definition of the concept and then again for the proof, as happens for the causality, then two things happen: or it is not sure if a certain topic concerns the concept or the proof, and it becomes difficult to mutually delimit, in an unambiguous and reasonable way, the areas of substantive and procedural law."
} 
evidentiary standards, criminal and civil, were "sculpted" by Judge Brennan in the famous ruling by the Supreme Court in 1970, King Winship ${ }^{51}$. These are the reasons: "In a civil suit between two private parties for money damages, for example, we view it as no more serious in general for there to be an erroneous verdict in the defendant's favor than for there to be an erroneous verdict in the plaintiff's favor. A preponderance of evidence standard therefore seems peculiarly appropriate, for [...] it simply requires the trier of fact to believe that the existence of a fact is more probable than its nonexistence before [he] may find in favor of the party who has the burden to persuade the [judge] of the fact's existence. In a criminal case, on the other hand, we do not view the social disutility of convicting an innocent man as equivalent to the disutility of acquitting someone who is guilty [...] I view the requirement of proof beyond a reasonable doubt in a criminal case as bottomed on a fundamental value determination of our society that it is far worse to convict an innocent man than to let a guilty man go free" (italics ours).

It is an argument that is rationally results oriented: "The standard of proof influences the relative frequency of these two types of erroneous outcomes. If, for example, the standard of proof for a criminal trial were a preponderance of evidence, rather than proof beyond a reasonable doubt, there would be a smaller risk of factual errors that result in freeing guilty persons, but a far greater risk of factual errors that result in convicting the innocent. Because the standard of proof affects the comparative frequency of these two types of erroneous outcomes, the choice of the standard to be applied in a particular kind of litigation should, in a rational world, reflect an assessment of the comparative social disutility of each" ${ }^{52}$.

What are, finally, the outcomes of the various forms of protection, prevalently civil law in the U.S. and the one "driven" by criminal law in Italy?

According to U.S. data, in the aggregate of lawsuits for malpractice filed each year, the subset of the victorious cases amounts to less than half of the total, and includes both "valid" and theoretically "invalid" cases: hence the use of expressions such as jackpot justice, or "lottery of lawsuits", to describe the quasi-random mode of compensation allocation ${ }^{53}$.

The data is confirmed by the empirical study conducted by Merrit and Barry in Ohio, according to which in only $30.7 \%$ of cases do patients obtain a victorious verdict

\footnotetext{
51397 U.S. 358 (1970).

52 These are the reasons for consent expressed by Judge Harlan in the Winship sentence. On the relationship between evidentiary standards and the costs of false acquittals and false convictions, see LAUDAN, Truth, Error, and Criminal Law. An Essay in Legal Epistemology, New York, 2006, 69, 87, in the sense that the evidentiary standard "incorporates the social contract about the acceptable relationship between true acquittals and false convictions". On the causality and evidentiary uncertainty about negligent conducts see BEEVER, Rediscovering the Law of Negligence, Oxford and Portland, 2007, 413 following.

${ }^{53}$ In a critical sense, see HYMAN - SILVER, op. cit., 1092 following, 1106.
} 
in court ${ }^{54}$ (in $38 \%$ of the cases, according to Jury Verdict Research ${ }^{55}$ ): a low rate, considering that, according to general statistics on tort trials, the actors win in $52 \%$ of the cases on average ${ }^{56}$.

Surely better, for patients, is the data related to extra-judicial compensations (which constitute the most common outcome of proceedings). These are granted more or less in half of the cases, even if normally for much less than the amount due ${ }^{57}$.

In the final analysis, surveys seem to show that the US tort system tends to undercompensate (both in absolute figures and in relation to the amount of the compensable damage), rather than over-compensate (as many believe) the victims of medical negligence (only in rare cases victims with minor real damages are slightly overcompensated $)^{58}$.

And the criminal responsibility of health professional in Italy?

Its function seems to be primarily of symbolic stigmatization: the effective execution of the sentence (especially in the detention mode) tends to become a rather remote eventuality:"Criminal law has been reduced to a kind of inoffensive mimicry"59, to quote Sgubbi.

It is mostly a problem of avoidance of sanctions, due to judicial indulgences in the application of conditions to suspended sentences.

The conditional suspension of punishment (extended in 1990 to accessory penalties), "in its distorted practical automatism, disregards - according to common opinion - every guarantee on the non-danger of the subject and every control and assistance" ${ }^{60}$. Conceived on the Anglo-Saxon model of probation, that is, the suspension of the sentence of condemnation (originallly aimed at the rehabilitation of the youngest defendants), in continental Europe turns into the suspension of the execution of the penalty. As a remedy for short prison sentences, enforced for occasional and unrepeatable

\footnotetext{
${ }^{54}$ MERRIT-BARRY, Is the Tort System in Crisis? New Empirical Evidence, 60 Ohio St. L. J. 315 (1999).

55 Care Health Providers Win Most Cases, in http://www.medicalmalpracticetoday.com/medicalmalpracticestats-hcpwinmore.html (statistic based on a national database of 193.500 verdicts and compensations for personal damages).

56 Medical Malpractice Trials and Verdicts in Large Counties, in http://www.medicalmalpractice.com/national-content.cfm.

${ }^{57}$ JAKIW, The Current Medical Liability Insurance Crisis: An Overview of the Problem, Its Catalyst and Solutions, 13 Annals Health L. 510 (2004); HYMAN-SILVER, paper cit., 1106: «On average, the actors recover aroung half of their losses [...] Medical malpractice cases also seem to take a longer time than other cases of tort».

${ }^{58}$ HYMAN-SILVER, paper cit., 1104; compare with Compensation Payments in Medical Malpractice Litigation, in http://www.medicalmalpractice.com/national-content.cfm.

${ }^{59}$ SGUBBI, cit., 90.

${ }^{60}$ MANTOVANI F., last paper cit., 760
} 
crimes, in Italy the suspension undergoes serious functional distortions, until its almost total deformation into clemency measure ${ }^{61}$.

This, first of all, because the Italian legislator has expanded its application range, regulating the possibility of a second concession, extended to convictions up to two years (also resulting from the sum of the first and the second convictions: a penalty limit which, normally, is not consistent with other legislations). Secondly, because the conditional suspension of the sentence, in practice, is applied almost automatically. As it is almost automatical for the judge to allow for "generic" extenuating circumstances.

And again: given that the detention penalty concretely imposed, taking into account the various reduction bonuses (up to a third, for example, in the case of alternative procedures) rarely exceeds six months, it is usually replaced, sic et simpliciter, with the pecuniary penalty. The latter (considered as a substitute sanction in Law n. 689/1981, Article 53, with the aim of containing short detention penalties) carries with it the traditional drawbacks of the pecuniary penalty in the Italian system. Mainly, a poor deterrent effect and a discriminatory character in favor of the upper classes (who, despite the theoretical graduation of sanctions, are less affected by intimidating powers).

With reference to negligent injuries, the fictive nature of punishment is revealed by means of the victim's complaint (procedural rule introduced with the 1981 reform): this prosecution regime often leads to a specious use of criminal justice, as a form of pressure to obtain an extra-judicial compensation. Compensation is indeed usually followed by the withdrawal of the victim's complaint, and therefore by waiver of punishment.

In Italy, the impression of a predominantly "symbolic" role played by criminal law in the field of medical guilt seems to have emerged.

\section{REFERENCES}

BARRINGER, A New Prescription for America's Medical Liability System, 9 J. Health Care L. \& Policy 241 (2006).

BEEVER, Rediscovering the Law of Negligence, Oxford and Portland, 2007.

BENCIVENGA, Le due americhe. Perchè amiamo e perché detestiamo gli Usa, Milan, 2006.

BLAIOTTA, Causalità e colpa: diritto penale e diritto civile si confrontano, in Cass. pen., 2009, 78.

BLOCH-McMUNIGAL, Criminal Law: A Contemporary Approach. Cases, Statutes, and Problems, New York, 2005.

\footnotetext{
${ }^{61}$ FIANDACA-MUSCO, paper cit., 769 following.
} 
CALABRESI-MELAMED, Property Rules, Liability Rules, and Inalienability. One View From the Cathedral, 85 Harvard Law Rev. 1089 (1972). https://doi.org/10.2307/1340059

CAVE BONDI-CIALLELLA, Medical negligence: inquadramento storico della responsabilità professionale nel diritto americano, in Iura Medica, 1995, 22.

CHESSICK-ROBINSON, Medical Negligence Litigation is Not the Problem, 26 N. Ill. U. L. Rev. 566 (2005).

COFFEE, Does “Unlawful” Mean "Criminal”?: Reflections on the Disappearing Tort/Crime Distinction in American Law, 71 B.U.L. Rev. 193 (1991).

DAMAŠKA, The Faces of Justice and State Authority, New Haven, 1986.

DI GIOVINE, La causalità omissiva in campo medico-chirurgico al vaglio delle sezioni unite, in Foro it., 2002, II, 612.

DI MARTINO, Il nesso causale attivato da condotte omissive tra probabilità, certezza e accertamento, in Dir. pen. e proc., 2003, 50.

DONINI, La causalità omissiva e l'imputazione per l'aumento del rischio. Significato teorico e pratico delle tendenze attuali in tema di accertamenti eziologici probabilistici e decorsi causali ipotetici, in Riv. it. dir. proc. pen., 1999, 32.

EDGAR, Mens Rea, in Encyclopedia of Crime and Justice, 1037 (1983).

FABBRINI, L 'America e i suoi critici. Vizi e virtù dell'iperpotenza democratica, Bologna, 2005.

FERRI, L'omicidio-suicidio, Turin, 1925.

FIANDACA-FRANCOLINI (eds.), Sulla legittimazione del diritto penale. Culture continentale e anglo-americana a confronto, Turin, 2008.

FIANDACA-MUSCO, Perdita di legittimazione del diritto penale?, in Riv. it. dir. proc. pen., 1994, 25.

FIORE, La teoria generale del reato alla prova del processo, Naples, 2007.

FIORI - LA MONACA - ALBERTACCI, Le Sezioni unite penali della Cassazione riaffermano l'esigenza di elevata probabilità logica del nesso causale nelle condotte mediche omissive: ma nel contempo confermano, pur dichiarando prescritto il reato, la responsabiità del medico in un caso di colpa e nesso causale poco probabili, in Riv. it. med. leg., 2002, 1605.

FIORI, Medicina legale della responsabilità medica, Milan, 1999.

FLETCHER, Basic Concepts of Criminal Law, Oxford, 1997.

FLETCHER, Dogmas of the Model Penal Code, 2 Buffalo Criminal Law Review, 3 (1998). https://doi.org/10.1525/nclr.1998.2.1.3

FORTI, Per una discussione sui limiti morali del diritto penale, tra visioni "liberali" $e$ paternalismi giuridici, in Studi in onore di Giorgio Marinucci, eds. Dolcini and Paliero, vol. I, Milan, 2006, 283. 
FRANCOLINI, L'harm principle nel diritto angloamericano nella concezione di Joel Feinberg, in Riv. it. dir. proc. pen., 2008, 276.

FRIEDMAN, American Law in the 20th Century, New Haven - London, 2002.

FRIEDMAN, History of American Law, New York, 1985.

GILMORE, The Ages of American Law, New Haven, 1977. https://doi.org/10.2307/1340363

GRANATA, L'omicidio nel diritto penale, Rome, 1960.

GREMBI, Una riflessione tra economia e diritto sulla malpractice medica: i casi di Stati Uniti e Italia, in Mercato, concorrenza, regole, 2005, 455.

HERRING \& PALSER, The Duty of Care in Gross Negligence Manslaughter, Crim. L. Rev., 2007, 24.

HUSAK \& SINGER, Of Innocence and Innocents: The Supreme Court and Mens Rea Since Herbert Packer, in 2 Buffalo Criminal Law Review, 860 (1999). https://doi.org/10.1525/nclr.1999.2.2.861

HYMAN-SILVER, Medical Malpractice Litigation and Tort Reform: It's the Incentives, Stupid, 59 Vand. L. Rev. 1085 (2006).

JAKIW, The Current Medical Liability Insurance Crisis: An Overview of the Problem, Its Catalyst and Solutions, 13 Annals Health L. 505 (2004).

LAUDAN, Truth, Error, and Criminal Law. An Essay in Legal Epistemology, New York, 2006. https://doi.org/10.1017/CBO9780511617515

LOEWY, Criminal Law, Eagan, Minnesota, 2003.

MANTOVANI F., Diritto penale. Parte Generale, Padua, 1992.

MANTOVANI, La "perenne crisi" e la "perenne vitalità" della pena. E la "crisi di solitudine" del diritto penale, in Studi in onore di Giorgio Marinucci, Milan, 2006, 1181.

MARINUCCI, Il diritto penale messo in discussione, in Riv. it. dir. proc. pen., 2002, 1041.

MATTEUCCI, Liberalismo, in Dizionario di politica, directed by Bobbio-MatteucciPaquino, Turin, 1990.

MELLO-STUDDERT, The Medical Malpractice System: Structure and Performance, in SAGE-KERSH (Eds.), Medical Malpractice and the U.S. Health Care System, New York, 2006, 11. https://doi.org/10.1017/CBO9780511617836.002

MERRIT-BARRY, Is the Tort System in Crisis? New Empirical Evidence, 60 Ohio St. L. J. 315 (1999). https://doi.org/10.2139/ssrn.179913

MULCAHY, Threatening Behaviour? The Challenge posed by Medical Negligence Claims, in FREEMAN \& LEWIS, Law and Medicine, New York, 2000, 102.

NUVOLONE, Diritto penale. I delitti contro il patrimonio e contro la persona, Milan, 1964. https://doi.org/10.1093/acprof:oso/9780198299189.003.0005 
PACKER, The Limits of Criminal Sanctions, Stanford, 1968.

PADOVANI, Il crepuscolo della legalità nel processo penale. Riflessioni antistoriche sulle dimensioni processuali della legalità penale, in Ind. pen., 1999, 541.

PIEMONTESE, Le problematiche della causalità omissiva: tendenze emergenti e modelli prasseologici, in Scritti in onore di Antonio Cristiani, Torino, 2001, 603.

RAO, Property, Privacy and the Human Body, 80 B.U.L. Rew. 359 (2000).

RESTA - ZENO ZENCOVICH, Informazione, consenso e responsabilità nei trapianti da vivente: prospettive nazionali e comunitarie, in Riv. it. med. leg., 2003, 969.

RODOTA', Ipotesi sul corpo “giuridificato”, in Tecnologie e diritti, Bologna, 1995, 180

RODOTA', La vita e le regole. Tra diritto e non diritto, Milan, 2006.

RODRIGUEZ VAZQUEZ, Doctors in Spanish Criminal Law: Medical Responsability for Death and Injuries caused by Negligence in Present-Day Spain, in 25 Medicine and Law 411(2006).

ROTHMAN, Strangers at the Bedside. A History of the Law and Bioethics Transformed Medical Decision Making, New York, 2003.

ROXIN, Risarcimento del danno e fini della pena, in Riv. it. dir. proc. pen., 1987, 12.

SANTALUCIA, Omicidio (dir. rom.), in Enc. dir., XXIX, Milan, 1969, 885.

SGUBBI, Il reato come rischio sociale, Bologna, 1990.

SILVA SANCHEZ, La expansión del derecho penal. Aspectos de la política criminal en las sociedades postindustriales, Madrid, 2011.

SIMONS, Dimensions of Negligence in Criminal and Tort Law, 3 Theoretical Inq. L., 283 (2002). https://doi.org/10.2202/1565-3404.1053

STELLA, L'allergia alle prove della causalità individuale, in Riv. it. dir. proc. pen., 2004, 379.

STUDDERT - BRENNAN - THOMAS, Beyond Dead Reckoning: Measures of Medical Injury Burden, Malpractice Litigation, and Alternative Compensation Models from Utah and Colorado, 33 Ind. L. Rev. 1643 (2000).

STUDDERT-MELLO-BRENNAN, Health Policy Review, in ANDERSON (Ed.), Medical Malpractice. A Physician's Sourcebook, Totowa, 2005, 230.

VANNINI, Delitti contro la vita, Milan, 1958.

VOLK, Sistema penale e criminalità economica, Naples, 1998. 